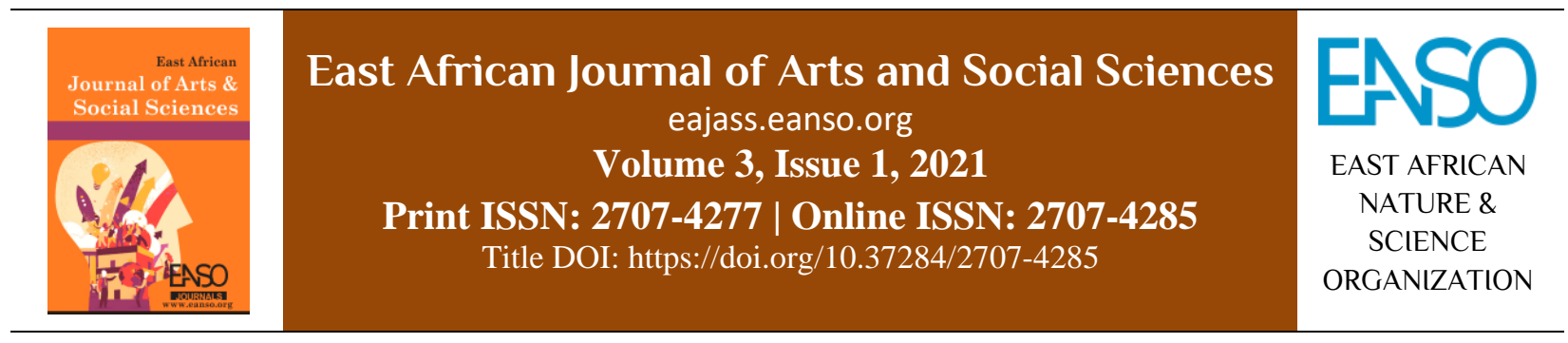

Original Article

\title{
The (Mis) Use of Language in Nigerian Political Campaigns (NPC): Moral Philosophical Perspectives
}

\author{
Mark Omorovie Ikeke, $P h D^{1 *}$ \\ ${ }^{1}$ Department of Religious Studies and Philosophy, Delta State University, PMB 1, Abraka, Nigeria. \\ *ORCID: https://orcid.org/0000-0001-9115-378X; Correspondence email: Ikeke7@ yahoo.com.
}

Article DOI: https://doi.org/10.37284/eajass.3.1.260

\section{Date Published: ABSTRACT}

05 January 2021 Language is an important instrument of communication in every society. Through it, human beings interact, relate, and forge ahead. Through language,

Keywords: human beings are able to adapt to their environment and make meaning out of life. It can be used for good or for evil. Language can be used properly or it can

Language, be abused or misused. This paper examines the use of language in political Nigeria, campaigns in Nigeria. It argues that language is often misused or abused in Politics,

Morality,

Campaigns. political campaigns in Nigeria. Language is used to cajole, intimidate, demean and degrade human dignity in Nigeria. Ethically the way language is used in political campaigns in Nigeria is unacceptable. The paper used a critical analytic and hermeneutic method to decipher the issues involved. It finds and concludes that there is a need for politicians to behave morally in their use of language during political campaigns to build a better society.

\section{APA CITATION}

Ikeke, M. O. (2021). The (Mis) Use of Language in Nigerian Political Campaigns (NPC): Moral Philosophical Perspectives. East African Journal of Arts and Social Sciences, 3(1), 1-11. https://doi.org/10.37284/eajass.3.1.260

\section{CHICAGO CITATION}

Ikeke, Mark Omorovie. 2021. "The (Mis) Use of Language in Nigerian Political Campaigns (NPC): Moral Philosophical Perspectives". East African Journal of Arts and Social Sciences 3 (1), 1-11. https://doi.org/10.37284/eajass.3.1.260.

\section{HARVARD CITATION}

Ikeke, M. O. (2021) “The (Mis) Use of Language in Nigerian Political Campaigns (NPC): Moral Philosophical Perspectives", East African Journal of Arts and Social Sciences, 3(1), pp. 1-11. doi: 10.37284/eajass.3.1.260.

\section{IEEE CITATION}

M. O. Ikeke, "The (Mis) Use of Language in Nigerian Political Campaigns (NPC): Moral Philosophical Perspectives", EAJASS, vol. 3, no. 1, pp. 1-11, Jan. 2021. 


\section{MLA CITATION}

Ikeke, Mark Omorovie. "The (Mis) Use of Language in Nigerian Political Campaigns (NPC): Moral Philosophical Perspectives". East African Journal of Arts and Social Sciences, Vol. 3, no. 1, Jan. 2021, pp. 1-11, doi:10.37284/eajass.3.1.260.

\section{INTRODUCTION}

Language is an important instrument of communication in society. Language is essential to political society. Political society exists for the provision of the good life for the citizens. Government is set up in political society so that there will be people to direct and lead the society to foster life, enhance liberty and promote happiness. In order for these to be obtained, democratic societies created political campaigns through which those competing for elective offices to govern society can present their manifestoes and programmes of action to the people. Those campaigning for political offices are called politicians, while the citizens that will vote them into power are called the electorate. During electoral political campaigns, politicians often make promises and use flamboyant languages to persuade the people to vote for them. As Nwolise (2011) writes, elections are vital aspects of democracy rooted in political participation, people's sovereignty, and rule by the majority, etc. While some may keep their promises to the people made during elections, many others do not. They make promises just to get votes and be in office. This makes their quest based on lies, fraudulent and immoral. They use Machiavellian strategies to get to and remain in power.

The above phenomenon is common in many countries in the global south, but the concern of this paper is Nigeria. The paper ethically examined and appraised the use of language by politicians in Nigeria. The paper then examined the authentic goals of political campaign and governance. This was followed by the use of language in Nigerian political campaigns thereafter an evaluation of the use of language in a political campaign in the light of the authentic goals of governance.

\section{LITERATURE REVIEW}

There are many issues involved in this paper that can be reviewed. There is the use of language, Nigerian politics, Nigerian political campaigns, and ethical perspectives. All the literature in all these areas cannot be reviewed exhaustively. The paper restricted itself to the literature on the use of language and its use with regard to political campaigns in Nigeria. Ako (2004) discusses how social stratification and class affect the use of language and how bilinguals make their choice of language. Omozuwa and Ezejideaku (2008) examined Nigeria's 2007 general elections and how politicians used stylistic language to carry out propaganda in powerful and often exaggerated messages as well as abusive utterances to persuade people to vote for them. Ezejideaku and Ugwu (2007) show that Nigerian politicians use rhetoric, linguistic propaganda and other devices in their campaigns, though their campaigns at times fail for many politicians are insincere, financially induce the electorate, intimidate, and even rig elections.

In Mohammed (2002) article, attention is devoted to deciphering the abuse and misuse of language in national and democratic processes in Nigeria. The paper also examined George Orwell's paper, "Politics and the English Language," and also Naomi Chomsky, "US Thought Control: The Middle East." Mohammed using Chomsky shows how the American government deliberately assigns new meaning to words (thus embarking on newspeak) to control the American mind. Ndimele and Owuamalam (2015) devoted their piece to how language in political advertising is used through the choice of words to demean and discredit opponents.

Aduradola and Ojukwu (2013) appraise man's political nature in campaigning for power and in the process, they use language positively or negatively. They argue that the use of communication and language should be to inform and persuade and not to merely entertain or deceive as many politicians do. Ademilokun (2019) takes the perspective of examining the use of language in Nigerian political campaign from a historical perspective and also zeroes on some political adverts of the 2015 election and analyses the verbal and non-verbal ways meaning was made through the advertisements. Ademilokun (2015) analyses that devices such as propagandistic language, allusion, 
code-switching with code-mixing, flattery and praise among others used in a political campaign. $\mathrm{He}$ equally examines the linguistic, political, cultural and social factors that affect the use of political campaign language in South-western Nigeria among two major political parties in 2011.

Daniel (2019) studies the role that language plays in Nigerian political processes and elections, especially with regard to the fact that Nigerian politicians have used language in a thug-like manner. They use language to intimidate and instil fear in others. Through a critical discourse analysis/grammatical analysis, he urges Nigerian politicians to use language to promote peace and non-violence while securing the lives and properties of citizens. Opeibi (2008) articulates the need for linguistic equilibrium in building a virile democracy in Nigeria and the effective use of political communication. Linguistic hegemony of one group over another is unacceptable, to him. In another article, Opeibi (2006) wrote of the negative campaigning that has come to characterise Nigerian political campaigns and describes it as "political macheting." Campaigns, instead of projecting positive values are used to attack and destroy the opponent. Taiwo and Oamen (2018) describe the use of visual communication in Nigerian newspapers to present the messages of politicians during campaigns.

The excursions through the above literature reveal that the question of the use of language in political campaigns in Nigeria has been studied from many perspectives such as sociologically, linguistically, politically and psychologically. The aspect that is missing is that of moral philosophical evaluation of the issues; hence the aim of this paper.

\section{Conceptual Clarifications}

Hassan (2006, p. 109) citing Crystal from the Encyclopedia states that "language is defined as a system of conventional spoken or written symbols by means of which human beings and members of a social group participate in its culture communicate." For Edward Sapir, as cited by Ogunsiji (2008, p. 181), "language is a purely human and non-instinctive method of communicating ideas, emotions and desires by means of a system of voluntarily produced symbols." Language is an essential part of the culture and one of the things that makes human beings social animals. It is human beings who are generally understood to communicate in the language. As further noted, Ogunsiji (2008), citing Wallwork, language is used for social regulation, the celebrations, taking actions, keeping records, influencing people, self-expression, communicating thought, and communicating information and orders. It is through language that human beings interpret the world in which they live and recreate it to facilitate their evolutionary struggle. Language performs a big social function in helping to construct social reality and identity function (Ng \& Deng, 2017, p. 1).

There is also the question of the use of language. Language is used differently in different social and cultural contexts. Language is a contextualized phenomenon. The way that language is used in a classroom setting is not the same way that language is used in a political campaign or in a religious worship service. The way that language is used in an office setting is different from non-office settings (Ako, 2004). Language use is affected by society and the use of language also affects society. Ako (2004, p. 21) says that:

Language use involves making linguistic choices and is located at all levels of language structure-phonological, morphological, syntactic, lexical and semantic. These can be applied individually, socially and regionally to yield what are technically referred to as idiolects, sociolects and dialects, respectively. The theory of language is often concerned with social prefunctional motivations underlying specific linguistics choices that language users make.

What is a Nigerian political campaign? The word, "campaign" refers to the "period immediately before the election, when candidates canvass for support" (Chaturvedi, 2006, p. 36). Political campaigns are geared to influence people's decisions on who to choose during elections (Aduradola \& Ojukwu, 2013).

Politics can be understood as the activities related to and the machinery for the governance of the state, together with all the decision-making processes and conflict resolution mechanisms 
(Chaturvedi, 2006). Okolie (2014) indicates that politics concerns direct or indirect activities directed at the common good of society. Okolie rightly notes in the place stated that if the common good is not enhanced them the reason for the existence of civil society is defeated. It should be noted that the business of governance should not only benefit the majority of the greater number of people, but the government should also work to bring good equally to the minority, the less privileged, the disadvantaged, etc. It is true that politics is not limited to the governance of the state, but the concern here is with the state. The term, Nigerian political campaign (NPC) was used in this paper to designate the period set aside for those vying for political offices (politicians) in Nigeria to persuade the electorate to vote for them.

\section{Theoretical Framework Adopted}

The paper will adopt the theory of I-Thou relationship by the German philosopher, Martin Buber. Buber (2002) sees the I-Thou (Ich-Du) relationship as dialogical, while I-It (Ich-Es) is monological. It is both a theory of relationship, interaction and communication. It is an "existential philosophy of dialogue" (Popova, 2018). For Buber, there are two fundamental forms of attitudes and relationships in this world. There is an I-Thou relationship and an I-It relationship. In the first, you see the other person is intricately related and not separate from you. You have a sincere relationship with the other person. But in I-It relationship, the other person is seen as an object separate from you. Because the other is seen as an object, the other can be controlled, dominated and oppressed.

Buber (2002) notes that authentic dialogue is essential to experiencing others in an I-Thou relationship. For him, an I-It relationship that is monological is turning to oneself and away from others. An I-It relationship way of seeing the world enslaves the other as the other is simply an object. The relevance of this theory to the subject matter of this work is that authentic and ideal relationships should be framed in an I-Thou communicative relationship. A fellow human being should not be objectified and experienced as an "it". The relationship between politicians and the electorate should be dialogical and mutually beneficial to both parties. What is presently experienced in Nigerian politics is that the relationship between many politicians with the electorate is objectified. The politician sees the citizens as simply instruments to help them gather votes to reach power. Once they get to power, the citizens are often forgotten as the politicians neglect many of the promises they made and selfishly enriched themselves to recover the money spent in the electoral campaigns. Politicians should not see the voters as passive receivers of their messages.

By defining their relationship with the electorate as an I-It relationship, politicians operate from a Machiavellian perspective. In his book, The Prince, the Italian political thinker opined that morality should be separated from politics. The prince or the ruler should be a pragmatist. He does not have to be just, honest or kind. All that matters is that he should do whatever is necessary to gain power and to stay in power. He should do whatever is expedient to be in power. He can pretend to be truthful and honest just to be in power. The paper affirms that this mindset and perspective politicians in Nigeria is unacceptable and should be morally condemned. Politicians ought to live in line with the authentic goals of political campaign and good governance.

\section{RESEARCH METHODOLOGY}

This paper adopted a qualitative research methodology. The paper will not be based on statistical procedures or quantification methods but is based on secondary sources. Materials, data and information on the use of language in Nigerian political campaign were gathered from books, journal articles, and online publications. The research presents what other authors have written on the subject matter, but it also interpreted and appraised them to make a contribution. It describes the reality and phenomenon of how language is used in political campaigns in Nigeria; hence, descriptive. It explored in a deeper manner the subject matter with the aim to understand it. This was coupled with a critical analytic and hermeneutic methods used to examine, dissect and unravel the phenomenon. The data gathered from the various written or textual sources were presented under the heading of conceptual clarification, the goals and aims of political campaign and governance, the use of language in 
Nigerian political campaign. The data or information from those sources is interrogated and analysed as the paper makes a moral philosophical or ethical appraisal of the subject matter.

\section{LANGUAGE USE AND NIGERIAN POLITICS}

\section{Authentic Goals of Political Campaign and Governance}

From a social contract perspective, the government has responsibilities to the people (Rousseau, 1968). Hobbes is also of the opinion that when the people surrendered their rights to the Leviathan, the Leviathan (government) acquired the obligation and responsibility to work for the welfare and wellbeing of the people (Hobbes, 1981). State political campaign is embarked upon for the purpose of governance of the state and this, in turn, is for provision of the good life for the citizens. The goals and objectives of governance normally appear in political campaign speeches, posters, and discussions. Political campaigns are not an end in themselves, but a means to an end.

Political power, political authority and government all exist to provide the optimal life for the people in terms of them getting the resources of life for their wellbeing and welfare. Among the functions of government are maintenance of law and order; promotion of economic activities; provision of social amenities; making and enforcing laws; protection of citizens; fostering friendly relations with other countries, among others (Akinbade, 2008). During political campaigns, politicians normally promise to carry out all these functions. They promise to do all these in their speeches or campaign posters.

The authentic goals of political campaigns should not be different from the purpose for which the political society exists and for which government is constituted. The purposes of both are almost coterminous or coextensive. Politics should be for service of the common and public good. Therefore, political campaigns should not be to enrich the politician or political party, but for the benefit of society. In their manifestoes, political parties state their objectives to benefit society and never for the benefit of the party. This is why it is a big contradiction when a politician and a political party come to power, they fail to maximally tend to the needs of society. These purposes include development and social progress of the people; advancing the wellbeing and welfare of the citizens; provision of economic opportunities for the people and equal access of citizens to those opportunities; securing the lives of the people from war, violence, hunger, social evils and ills; protection of lives and properties; guaranteeing their human rights such as rights to a healthy environment, food, water, life, liberty, happiness, political participation, among others.

The paper is not unmindful that there are scholars who draw a distinction between politics and governance. Odimegwu (2008) writes that these scholars see government as "institutional framework of the rule in the state" which is inclusive of the functions of the executive, the legislature, and the judiciary. Thus, the government is the machinery of the state to carry out its functions. The implication government is inherently political, but not all political activities constitute the government. Politicians, political parties and all that is associated with them are not a government, but when they capture political power, they become part of the government. This is why it is important for the major goals of politicians and their parties to align with the state and not conflict with it. Both politicians and political parties should act for the good of the political society.

When politicians campaign for political powers, they are opting to be the agents in the governmental process to bring about the realizations of the aims and objectives of the government. It is a contradiction that after using language to persuade the people and coming into office, politicians abandon this vision and settle for primitive accumulation of money to enrich themselves to the detriment of the wellbeing of the people treating the people as objects or things.

\section{How Language is used in Nigerian Political Campaigns}

The intention was to present the ways that language has been used in political campaigns in Nigeria. Some salient and few ways, especially the ways that are unethical so as to provide a basis for the moral- 
philosophical examination, was adopted. During elections in Nigeria, politicians sign pledges, make promises to abide by electoral rules and regulations; but the fact is that these pledges are broken as the elections are rigged by some politicians and political parties.

There is much linguistic violence or violent use of language to harm the opponent during electoral campaigns in Nigeria. For instance, Omitola (2011, p. 238) notes that "Campaign conflicts: can occur as rivals seek to disrupt the opponents' campaigns, intimidate voters and candidates and use threats and violence to influence participation in voting." Language is used to intimidate and threaten the followers of the opponent. They are threatened with punishment if they vote for the opponent. That some Nigerian politicians used negative language as corroborated by Professor Wole Soyinka, who opined that politicians use crude, vulgar, and abusive language in their campaigns (Alike, 2015).

Political campaign language in Nigeria is rhetorically persuasive. Many Nigerian politicians often speak in messianic terms as if they are the only qualified candidates and the only ones who can help the people. They see themselves as saviourfigures. They use languages like: "the chosen one," "the sent one," "the one the people have been waiting for," "the anointed one," "our only redeemer," etc. Language is used to entice and even "bewitch" the people.

In Nigeria, many politicians see political power as a means of financial and wealth accumulation. Because of this, they are willing to cajole people and paint their opponents in caricature when they are campaigning for votes. With regard to the directive function of language, Mohammed (2002) asserts that in Nigeria politicians use language to misinform, mislead and even cover-up issues; they doublespeak to control people (to use a George Orwellian idea). Double speaking amounts to insincerity and degrades human personality. Citing Orwell further, Mohammed (2002, p. 102) writes that: "political language ... and with variation, this is true of all political parties....is designed to make lies sound truthful and murder respectable and to give an appearance of solidity to pure wind." For many Nigerian politicians, politics is a "game" to acquire wealth and power and it does not matter even if empty and flippant words are used (Mohammed, 2002).

There is a fundamental lack of taking the truth seriously in NPC. Hassan (2019) states that political parties have weaponized disinformation to spread fake news, inaccurate information, and lies to harm the other parties. She notes that they even hire people who spread disinformation through the new media such as YouTube, Face book, Twitter, etc. such as that done by the Fulani Nationality Movement, a faceless group. Szanto (1978, p. 7) writes of political language thus: "lexicon of conflict and drama, of ridicules, and reproach, pleading and persuasion, colour and bite permeated. A language designed to valour men, destroy some and change the mind of others."

Propaganda is common in political campaigning in Nigeria. Propaganda according to Igwe (2005) is active and intense promotion of one's viewpoints with the aim to persuade to one's position over the opponents' ideas. There is nothing wrong in propaganda in itself; it is just that often some politicians exaggerate and manipulate through their words. They demonise their opponents and whatever achievements their opponents in power have accomplished are minimalized. Propaganda often comes with exaggeration. Omozuwa and Ezejideaku (2008, p. 42-43) quote from the Daily Sun of 2007 as follows:

They told us they had reformed the economy. Which economy? No Electricity! 95\% of business and homes depend on generator for electric power, no fuel! Government imports $100 \%$ of petroleum products for local consumption. Insensitivity! Our roads are death traps; infrastructure are derelict. Insecurity! Security of lives and property almost nonexistent. Poverty! There is absolute hunger and unemployment in the land....And now they tell us election will be a do or die affair? Nigerians will be alive to enjoy the real benefit of democracy. Vote ORJI UZOR KALU.

You can see the language of exaggeration above. The politician has not done any research to know that $95 \%$ of homes and businesses are without electricity. Another common way that language is used in political campaigns in Nigeria is through vague and unclear utterances. On this, Omozuwa 
and Ezejideaku (2008) write "politicians, in their desperation to discredit their opponent, use some utterances that may be termed abusive." Look at the example below from these two authors just mentioned who cites the Sunday Independent of February 2007:

"Later I made Segun Mimiko Minister without the knowledge of Agagu. What I am hearing now is that he said I am the one that urged him to go and contest in another party. He is a liar; I did not say any such thing. When he told me that he wanted to resign as Minister to go and contest, I begged him not to go; I don't know whether his mother's rival cursed him." (Omozuwa \& Ezejideaku, 2008, p. 45)

Language is used in an abusive way by many politicians. Take the following quotation from the Punch Newspaper of Friday, 16 March 2007. In the April 2015 presidential elections in Nigeria, Ndimele and Owuamalam (2015, p. 19) cite one presidential candidate attacking another one saying: "see who wants to become president." See some other threatening remarks made by Nigerian politicians cited in Daniel (2019, p. 8):

Chief Olusegun Obasanjo: ... this election is a do or die affair for me and the PDP. This election is a matter of life and death for the PDP and Nigeria. (Daily Trust, 12 February 2007 in a political campaign rally at Abeokuta, Ogun State)

General Muhammadu Buhari: God willing, by 2015, something will happen. They either conduct a free and fair election, or they go in a very disgraceful way. If what happened in 2011 (alleged rigging) should again happen in 2015, by the grace of God, the dog and the baboon would all be soaked in blood. (The Punch, 9 April 2014 in a meeting with party members in Kaduna, Kaduna State.)

Chief John Odiegie Oyegun: Jega is sitting on an iceberg and he does not know what is under him. The consequences of rigging this election will be undesirable. (The Punch, 8 August 2014 at a press conference in Osogbo, Osun State) President Goodluck Jonathan
The abuse and misuse of language have serious moral and political implications for society. It can affect the outcomes of elections as people are induced to vote for candidates that they would never have voted for. This is serious for good governance. Inept and incapable leaders are brought into the office. The moral responsibility of voters can be seriously impeded when they are induced or enticed with lies. The fact is that elections are crucial to vibrant democracies and progressive societies. When the process that makes leaders emerge for political society is vitiated and manipulated, it negatively affects the obtaining of the good life and welfare in that society.

\section{Ethical Evaluation of the Use of Language in the Nigerian Political Campaign}

It is important to morally appraise the use of language during elections for elections, as noted previously, are crucial to democratic societies. The interest of a philosopher from a moral perspective with regard to political-electoral processes will be to see to it whether language is used in a morally upright manner to promote the wellbeing and welfare of the people. Language should foster the goals and objectives of political governance. When it is not used in this manner, it amounts to abuse and misuse of language and this is morally unacceptable. Ehiakhamen (2001) notes that in language philosophy, language should be used to organize, create, formulate and symbolise the world and to see whether it is used to create or destroy. It should certainly be used to create and not destroy. It is pathetic when some politicians use language to destroy and degrade society and human personality. Language is used selfishly in political campaigns for individualistic reasons.

It is important to note as Hassan (2006) states that through language, knowledge is imparted, skills are acquired, and attitudes and values are transferred. Every form of language transfer attitudes and values and informs people's moral behaviours. This is inclusive of the language of politicians. The wrong example and influence of elderly politicians will affect the younger generations. The wise Chinese philosopher Confucius called for the "rectification of names" which implies, among other things that the words or speech of the politician should match their actual conduct indeed. 
Niworu (2008) citing Aristotle and Plato notes that the political society exists to promote civic virtue, the common good, and perfection of the people; but what we have in Nigeria is political violence, electoral deceits, lies, and promises that are not kept. Social and political lives are built on trust and bond. Whenever there is no basis on which human beings can trust another, political society is doomed to break down and crumble. The legitimacy of political authority is founded in government meeting the needs of the citizens. Even a philosopher like Hobbes, who advocated for a Leviathan, recognized that political authority could lose legitimacy if they fail to meet the needs of the citizens.

When political authority loses legitimacy, it can lead to conflicts, civil unrest, protests, and even violence. All these are not good for promoting peace and progress of society. This is why it is very important for politicians to fulfil their campaign promises. It is not something to be taken lightly. The question of legitimacy is crucial for political society. Besides "legitimacy by procedure," "legitimacy by representation," legitimacy by results" is more important and can even override the others (Okolie, 2014). Legitimacy by results refers to those in the political office providing justice and fulfilling the mission of government (Okolie, 2014). It was Augustine who taught that a nation without justice is simply made up of a gang of robbers. Those who have campaigned for political office and find themselves in government should serve the people they are called to serve and not engage in corruption and embezzlement of public funds.

In Nigeria, the rights to freedom of conscience thought, political expression and association are often suppressed. Posters of politicians are torn and their billboards pulled down by opposition parties and politicians. It is immoral to deny people their fundamental human rights. These rights are not given by society, but they are inalienable to humans. They are only recognized by society. The tearing of the posters and billboards of politicians limit people's knowledge of those politicians and the words and writings in their posters that ought to have been seen by many persons. When campaign posters are torn and billboards pulled down, politicians often trade words and nobody accepts responsibility for what has been done. The way that political campaigns are carried out in Nigeria, the genuine freedom of speech and association of the opponent is not respected. Political parties and politicians speak as if everybody must belong to one party and if you are not in their party, you are an enemy and should be destroyed.

Freedom of movement and association are vital bedrocks for the survival of political societies. Experiment, communist or socialist one-party states have either all failed or are failing in Africa, the former Soviet Union, or elsewhere. There should be space for genuine political pluralism and difference in the Nigerian political climate. Incidents of one political party burning the campaign offices of other political parties or tearing their posters should be things of the past. It was reported in Kogi State in the 2019 elections of how the state secretariat of the Social Democratic Party was burnt down by thugs (Odogun, 2019). Earlier before the burning of the secretariat banners, political posters and other campaign materials of the party were destroyed, and the campaign posters were replaced by that of another party. There should be room for different political ideologies and visions of how the Nigerian society can be organized from various political parties. No should intimidate other parties out of existence.

Using abusive and offensive languages and committing linguistic violence in political campaigns offends human dignity and rights. Every human being is entitled to the dignity of their personhood and humanhood and should be protected from abusive languages. Ikeano (2018) note how the language of Nigerian politicians is vitriolic, venomous without moral boundaries, unrestrained, lacks decency, decorum, insulting, cursing and demeaning. Ikeano states how former Governor of Lagos State Akinwumi Ambode called his rival in the APC primaries a criminal and drug addict. He also recalls how former president, Goodluck Jonathan called his predecessor a tout in the motor park. In many of the cases in which Nigerian politicians have used injurious and harmful words to describe their rival, they rarely apologise. Many Nigerian politicians are vindictive and unforgiving. These are signs of immaturity and unbecoming of those struggling for political office. Humility and ability to recognize mistakes and 
correct them or make amends are virtues of gentlemen. The virtues that should characterise the life of those aspiring for power is lacking in many. Ikeano (2018) rightly notes that: "Our political leaders of whatever hue should remember that they serve as role models, and this should reflect in all their conducts in thoughts, words and deeds."

Another important issue to be considered and it has serious ethical implication is that the people have a right and are entitled to enjoy the "dividends of democracy" or the benefits that should come from government. The government should seek to improve the lives of the people, provide a better life, guarantee their human rights, enhance the provision of food and amenities of life, etc. When the people are deceived through flippant political campaign speech and flamboyant promises, many politicians that come to power are unable to deliver. To cover-up their failures; politicians use "rationalise operational excesses and shortcomings" to magnify their achievements by spending millions of naira in paid advertorials, advertisements in which they praise and support themselves describing themselves as, 'progressive," 'dynamic," "visionary," "action governor," etc.; enumerating and exaggerating the social projects that have done all with the aim of winning re-election (Mohammed 2002, p. 142143). They use hyperbolic and exaggerated languages to describe themselves and their achievements. The citizens are deprived of the benefits of government, but politicians make them believe they have delivered.

\section{CONCLUDING REFLECTIONS `}

This paper agrees with Aduradola and Ojukwu (2013, p. 110)

Political candidates should strive to practice politics without bitterness by making frantic efforts to inform or persuade electorates rather than deceive them with enticing words. They should adopt simple expressions to communicate their political agenda without the use of force, violence, destructive tendencies and unhealthy rivalry. As much as possible, they should avoid negative expressions that can promote conflict during political campaigns.
Politics is essentially an ethical endeavour aimed at improving the lives of men and women in political society. Almost all the social and political philosophers agree on this from Socrates to Plato, through Aristotle to Thomas Aquinas, Augustine, Rawls, etc. In the exercise of politics and governance of social language and communication are essentials. Language and communication should be used in such a manner to promote the common good of the citizens and not for the political successes of politicians or to amass wealth and riches. It behoves politicians in Nigeria and elsewhere to use language that is ethical to build the personhood and personality of the citizens and not to objectify them. It is important for politicians in Nigeria to develop an "I-Thou" relationship of dialogue and mutual enrichment with the people not monologically dominating relationship. If they can do this, political campaigns in Nigeria will become linguistically and aesthetically something to behold.

\section{REFERENCES}

Ademilokun, M. (2019). A multimodal discourse analysis of some newspaper political campaign advertisements for Nigeria's 2015 elections. Abuja, Nigeria: The Independent National Electoral Commission (INEC). Retrieved from https://www.inecnigeria.org/wpcontent/uploads/2019/02/Conference-Paper-byMohammed-Ademilokun.pdf

Ademilokun, M. A. (2015). Discursive strategies in selected political rally campaigns of 2011 elections in southwestern Nigeria. International Journal of Society, Culture \& Language, 3(1), 120.

Aduradola, R. R., \& Ojukwu, C. C. (2013). Language of political campaigns and politics in Nigeria. Canadian Social Science, 9(3), 104116.

Akinbade, J. A. (2008). Government Explained. Lagos: Macak Book Ventures.

Alike, E. (2015). Nigeria: Soyinka Condemns Use of Crude, Abusive Language by Politicians. Retrieved from https://allafrica.com/stories/201503111002.htm 1. 
Ako, M. A. (2004). Class in Language Choice and Use in a Nigerian Bilingual Context. Ibadan Journal of Humanistic Studies, 13 \&14: 17-32.

Chaturvedi, A. K. (2006). Dictionary of Political Science. New Delhi: Academic India Publishers.

Daniel, I. O. A. (2019). Nigerian Politicians, Linguistic Rascality and the Security Implications. Retrieved from https://www.inecnigeria.org/wpcontent/uploads/2019/02/Conference-Paper-byIyabode-Omolara-Daniel.pdf

Ehiakhamen, J. O. (2001). Language and Feminism. Current Viewpoint: A Review of Culture and Society, 3(1 \&2), 20-24.

Ezejideaku, E., \& Ugwu, E. (2007). The Rhetoric \& Propaganda of Political Campaigns in Nigeria. Journal of the Linguistic Association of Nigeria, 10, 9-26.

Hassan, I. (2019). Nigerian political parties are weaponising fake news. Retrieved from https://mg.co.za/article/2019-02-21-nigerianpolitical-parties-are-weaponising-fake-news.

Hassan, S. O. (2006). Language education for reconstruction and empowerment in Nigerian society. Zaria Educator, 2(1): 109-112.

Hobbes, T. (1981). Leviatan, edited by C.B. MacPherson. London Penguin Books.

Igwe, O. (2005). Politics and Globe Dictionary. Aba: Eagle Publishers.

Ikeano, V. N. (2018). The language of our politicians. Retrieved from https://www.dailytrust.com.ng/the-language-ofour-politicians.html.

Mohammed, A. (2002). Democracy and Language (Ab)Use-Implications for National Development. In Ogude, S. (Eds.), Towards an African Renaissance (p. 99-127). Ibadan: The Nigerian Academy of Letters.

Niworu, S. M. (2008). The Politics of Tenure Elongation: A Renunciation of Democratic Values and Nation Building in Nigeria. In Adeniji, L. A. A. Adeyemo. S \& Adeniji, D. R.
(Eds.), Nigerian Democracy: The Journey So Far (p. 227-232). Ibadan: Jilat Publishing Company.

Odimegwu, I. (2008). Philosophic Foundations of Politics. Amawbia: Lumos Nigeria Limited.

Odogun, G. (2019). Kogi election: Thugs burn down SDP secretariat. Retrieved from https://punchng.com/kogi-election-thugs-burndown-sdp-secretariat/

Ogunsiji, A. (2008). Utilitarian Dimensions of Language in the Multilingual-Multicultural Nigerian Context. In Babawale T. \& Ogen, O. (Eds.), Culture and Society in Nigeria (p. 180199). Lagos: Concepts Publications Limited.

Okolie, A. (2014). Meaning and Nature of Politics." In Aloysius-Michaels Okolie, Onyemaechi A Eke, and Paul A Areo (Eds.), Politics and Law in Africa, 1-13. Abakaliki: WillyRose and Appleseed Coy.

Omitola, B. O. (2011). Political Parties' Competition, Electoral Violence and Democratic Consolidation in Nigeria's Fourth Republic, 1999- 2009. In Ogundiya, I. S. (Ed.), Political Parties and Democratic Consolidation in Nigeria, (p. 232-261). Ibadan: Codat Publications.

Omozuwa, V. E. \& Ezejideaku, E. U. C. (2008). A stylistic analysis of the language of political campaigns in Nigeria: Evidence from the 2007 general elections. OGIRISI: a New Journal of African Studies, 5(1), 40-54.

Opeibi, T. (2006). Political Marketing or Political, 'Macheting'? A Study of Negative Campaigning in Nigerian Political Discourse. In Muhr, R. (Eds), Reproduction and Innovation in Language and Communication in different Language Cultures.

(2008). Language, politics and democratic governance in Nigeria: a sociolinguistic perspective. Journal-Issues in Political Discourse Analysis, 2(2).

Ndimele, R. \& Owuamalam, G. (2015). Language Use in Political Advertising- A Rhetorical Discourse on "See Who Wants to Be President 
of Nigeria. Global Journal of Arts, Humanities and Social Sciences, 3(8), 19-31.

Ng, S. H., \& Deng, F. (2017). Language and power. In Oxford Research Encyclopaedia of Communication. Oxford University Press.

Nwolise, O. B. (2012). Elections as Threats to National Security: The Cote d'Ivoire Experience. Nigerian Journal of International Affairs, 37(1), 27-52.

Popova, M. (2018). I and Thou: Philosopher Martin Buber on the Art of Relationship and What Makes Us Real to One Another. https://www.brainpickings.org/2018/03/18/iand-thou-martin-buber/

Rousseau, J. J. (1968). The social contract. Trans by Maurice Cranston. Middlesex: Penguin Books.

Szanto G. H. (1978). Theatre and Propaganda. Austin: University of Texas Press.

Taiwo, R., \& Oamen, F. (2018). Perspectivation in Nigeria's Political Visual Communication: A Social Semiotic Analysis. Covenant Journal of Language Studies, 6(2), 1-22. 